\title{
Complex Representation of Natural Heritage on the Basis of WebGL. Shushensky Bor Information System
}

\author{
Nikita O. Pikov, Maria E. Romanuk, \\ Ivan N. Rudov and Maxim V. Rumyantsev* \\ Siberian Federal University \\ 79 Svobodny, Krasnoyarsk, 660041, Russia
}

Received 18.04.2018, received in revised form 06.08.2018, accepted 15.08.2018

The article deals with the problems and possibilities of preservation and representation of objects of the cultural and natural heritage in Russia with application of modern information technologies. The authors carried out an analysis of the representation of specially protected natural territories in the Internet in terms of the technologies used. The result of the analysis showed that at present the methods of presenting national parks, reserves, natural areas with tourist potential do not correspond with the potential of modern IT solutions and have a low degree of attractiveness for the end user.

The article gives the examples of IT solutions that can be used to popularize the historical, cultural and natural heritage, but they are not used in this field. Those IT solutions include WebGL, 3D-panoramic photography, html 5, 3D modeling technologies.

Based on the analysis carried out, the article presents the concept of an integrated information system for the representation of natural heritage, using the example of Shushensky Bor National Park. Besides, it also describes the stages of the system development and the methodology for creating such information systems. The article includes the screenshots of the Shushensky Bor information system, presents the logic of sections and navigation through the system. The final part of the article describes the characteristics of software and equipment that is necessary to obtain high-quality content about a natural heritage site and to ensure the functioning of an integrated system for its representation.

Keywords: three-dimensional graphics, 3D modeling, virtual tour, visualization, natural heritage, representation of natural heritage, national park, nature reserve, information system.

The research was carried out with the support of the regional state autonomous institution "Krasnoyarsk Regional Fund for the Support of Scientific and Technical Activity" within the framework of the project "Information System for Conservation and Representation of Natural Heritage (based on the example of Shushensky Bor National Park protected natural area)".

Research area: System analysis, information management and processing (by fields).

(C) Siberian Federal University. All rights reserved

* Corresponding author E-mail address: nikita.pikov@mail.ru; rudov.ivan@gmail.com; m-rumyantsev@yandex.ru; make.event10@gmail.com 
Citation: Pikov, N.O., Rudov, I.N., Rumyantsev, M.V., Romanuk, M.E. (2018). Complex representation of natural heritage on the basis of WebGL. Shushensky bor information system. J. Sib. Fed. Univ. Humanit. soc. sci., 11(8), 1315-1326. DOI: 10.17516/1997-1370-0308.

\section{Introduction}

The problem of conservation and representation of natural heritage sites is one of the key issues in the effective implementation of the cultural policy of modern Russia. To date, there has been an increase in interest in reserves and national parks, a change in the structure of the industry for the development of domestic tourism. Besides, some steps have been taken to promote the country's tourism opportunities to attract domestic and foreign tourists (Cipolla Ficarra, 2011; Talavera, 2012).

The urgency of resolving these issues is determined by such documents as the "Strategy for the Information Society Development in the Russian Federation" (2008), the State Program of the Russian Federation "Information Society 2011-2020" (2010). The significance of the formation of electronic information resources is discussed in the State Program of the Russian Federation "Information Society (2011-2020)", which states the need to create socially significant content that corresponds to the priorities of the country's development.

The importance of addressing the issues of the formation of electronic information resources is also determined by the fact that the structure of the federal target program "Culture of Russia (2012-2018)" includes special sections, such as "II.1. Digital content and preservation of cultural heritage" and "II.2. Ensuring an access to the cultural heritage in a digital form", in which the creation of digital content about significant events in Russian culture and art, the creation and development of electronic information resources of libraries, the creation of multimedia information resources about culture, interactive maps of cultural and natural landscapes of Russia, the research of issues of information security of cultural heritage and accessibility of cultural and historical information in modern society, the creation and support of Internet resources about culture, the creation of multifunctional mobile cultural centers to provide citizens with an access to Russian electronic information resources, including those located on the Internet, etc. are a priority.

The active incorporation of information technologies into the modern socio-cultural context significantly influenced the search for ways of relevant presenting the cultural and natural heritage that is a national treasure. Modern technologies of digitization and visualization allow fixing and saving in digital form not only individual objects, 
but architectural ensembles of the city and natural landscapes as well. Such methods of representing natural heritage as a web site (of a park, a nature reserve, etc.), a virtual tour based on panoramic shooting, a 360 panoramic video, an interactive map, an electronic catalog are widely used (Lukina, 2008).

Unfortunately, at present information on cultural-historical and natural heritage is often placed on various data sources, not tied to cartographic information, which creates certain inconveniences and does not correspond to the modern form of providing information to the user.

\section{Statement of the problem}

Our goal was to develop an information system for the conservation and representation of the natural heritage of the protected natural area, which represents and actualizes the unique natural heritage site Shushensky Bor National Park. The Shushensky Bor belongs to the category of specially protected natural areas of federal importance and is an environmental, ecological, educational and research institution. The unique natural and territorial complex of the Western Sayan and Minusinsk hollow was established in 1995 with the aim of preserving the natural complexes of the south of the Krasnoyarsk Territory, representing a wide range of ecosystems - from alpine meadows to forest-steppe. Especially valuable natural objects of the park are extrazonal pine ribbon forests located outside the main distribution area; lacustrineboggy complex that is a landscape relic of the glacial period; mountain cedar forests.

The only national park of the Krasnoyarsk Territory is characterized by a variety of landscapes, as well as a wealth of archaeological and historical monuments. The remains of human settlements of the bronze and iron centuries, the Omaytura fortress, the Sayan jail, the first settlement of Russians along the upper Yenisei were found on the territory of the Shushensky Bor.

The urgency of creating the Shushensky Bor information system is associated with the lack of both necessary and sufficient information about the reserve at the moment for detailed acquaintance with it for advertising educational, research purposes. Possible tourists have no idea of the uniqueness of the territory of the reserve, educational institutions do not have visual and factual material for the translation of knowledge, researchers do not have exact data for work, while the Shushensky Bor is an attractive territory for investors, which is favorable for recreation and tourism. In addition, it has an almost unlimited educational resource, which is presented to a potential visitor to a very small extent (Leonov, 2010), (Leonov, 2011). 


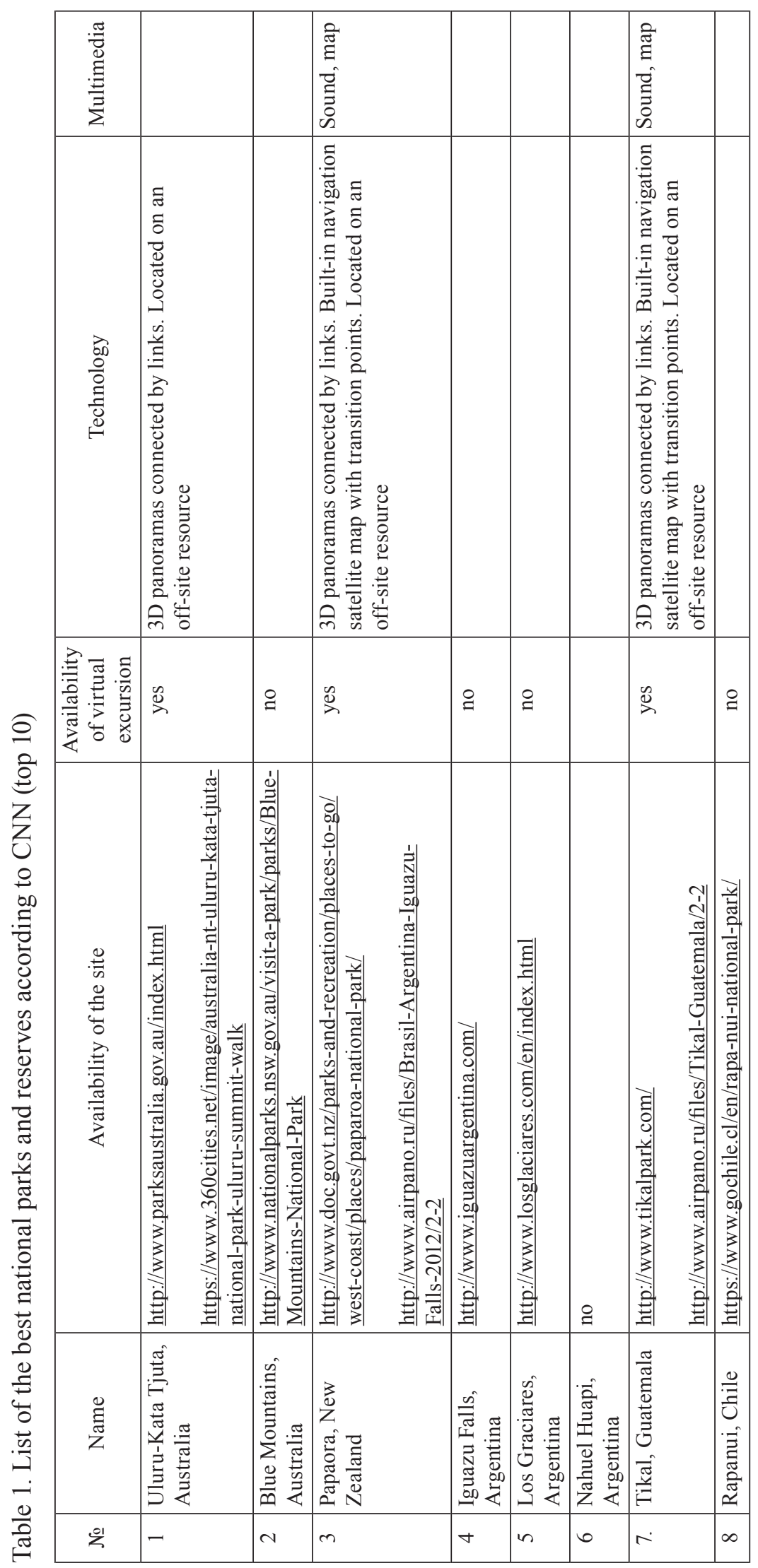


The stage of the creation of the concept of the Shushensky Bor electronic information system was preceded by a review and analysis of the world experience in the development of such resources, during which an assessment of existing web-offices of foreign and domestic parks and reserves containing virtual tours on their pages was made.

Before completing the task of developing Shushensky Bor information system (Table 1), 186 sites of national parks and reserves were studied. They included 155 sites of Russian national parks and reserves listed on the basis of the site data on specially protected natural areas of the Russian Federation, supported by the Ministry of Natural Resources and Ecology of the Russian Federation (Kucharska, 2011), and the top 30 best national parks according to $\mathrm{CNN}$.

The analysis of the best practices of applying information technologies in the field of preservation and representation of the natural heritage determined the main constructive solution of this project that is to develop a unique information system combining two visualization technologies offering complex visual and factual information (a topographic interactive map representing the biosphere potential of the park, 3D panoramas significant places, a catalog of flora and fauna, a description of tourist routes) (Ryan, 2014).

\section{Methodology}

Uniqueness, safety, diversity, the opportunity to study, observe, determine the place and significance nationwide is what makes the park a national treasure. Thanks to the inclusion of a complex of electronic resources in one information system, the unification of historical, archaeological, sociocultural and architectural data of multipurpose use, the project becomes truly interesting and unique in its kind. It became obvious that the use of WebGL and 3D-panoramic photography, which are two leading visualization technologies, will make the resource multifunctional and multi-purpose, taking into account the full range of possible user requests, such as satisfaction of interest in this subject at the educational, scientific, aesthetic, emotional level, as well as considering a possibility of the leisure use of the territory, which brings funds for the development of the national park (Hashim, 2010), (Remondino 2011).

At the initial stage, a technical assignment was prepared. It determined the main characteristics of the forthcoming development.

Then the following tasks were accomplished:

1. Collection of topographic information, photogrammetric digitization of the landscape elements for its further construction and photographing the flora of the reserve; 
2. Creation of a digital database describing the flora and fauna of the reserve, which helps the user to focus on the key places of the park, particularly rare vegetation, a diverse fauna;

3. Development of a three-dimensional interactive map of the national park, giving an idea of the scale, diversity and richness of the place;

4. Development of Shushensky Bor information system;

5. Designing a multimedia program-shell information system.

An important task was to implement a virtual tour using WebGL technology, which would allow reproducing the navigation 3D model of the map on all hardware devices, including personal computers and mobile devices, without installing additional software and on all the most popular browsers.

The panoramas of the national park were photographed using professional devices:

a) Canon 5DMarkIII DLR camera (Fig. 1) - EOS 5D Mark III - full-frame mirror 22.3-megapixel camera with 61-point autofocusing and 6 frames / second continuous shooting mode;

b) Wide-angle lens Sigma 15mm EX DG Fisheye (Fig. 2) - a high-speed ultrawide-angle full-size lens of a diagonal fish-eye type. Designed for digital full-format SLR cameras, it can also be used for film cameras. The diagonal fish eye creates an image on the entire frame with barrel distortion by an exaggerated perspective and a viewing angle of 180 degrees along the diagonal, which cannot be obtained by the human eye;

c) Manfrotto 755XB Tripod (Fig. 3);

d) Panoramic head Manfrotto 303SPH (Fig. 4), designed for shooting cubic panoramas. With the help of 303SPH, you can lock the camera in any position. The head allows you to rotate the camera both horizontally and vertically in a circle. Using the $303 \mathrm{SPH}$ ensures that the software used to connect the photos will create more accurate panoramic shots with minimal changes;

$303 \mathrm{SPH}$ allows you to rotate the camera in a circle at a single point with a constant rotation angle and create a "cubic" $\left(360^{\circ} \times 360^{\circ}\right)$ panorama.

The captured images were saved in the RAW format.

For the processing of the footage, the following software was used:

a) Canon Digital Photo Professional v. 3.14.40.0 - a high-performance software that allows you to process, view and edit RAW images.

b) Adobe Photoshop CS6. Adobe Photoshop - a multifunctional image editor. 


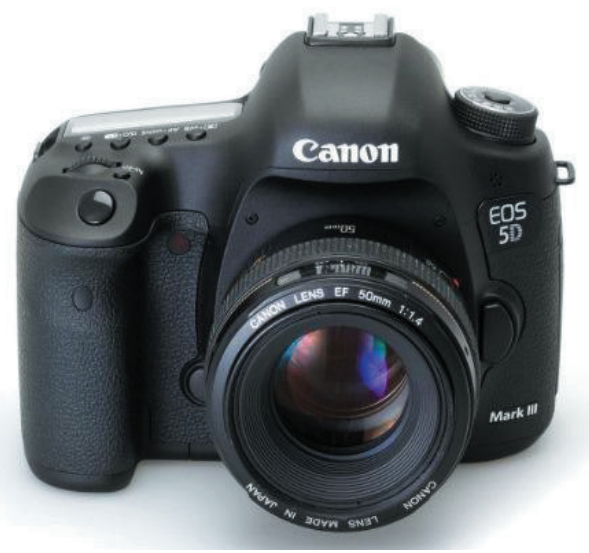

Fig. 1. Canon 5DMarkIII

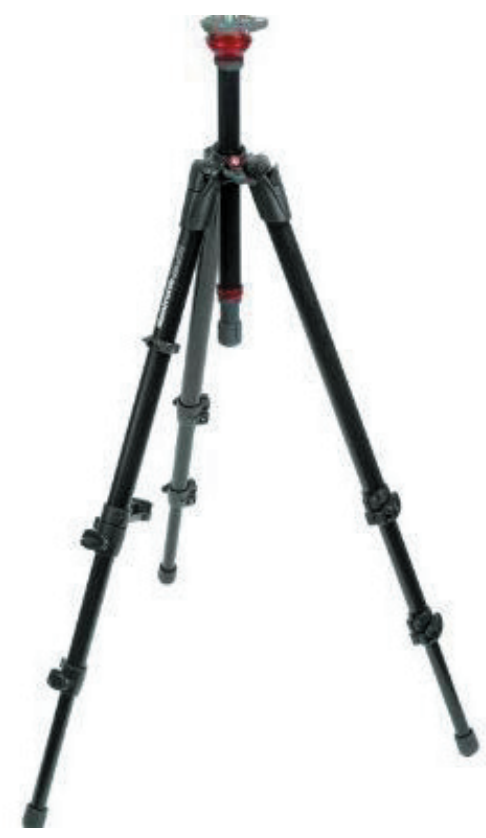

Fig. 3. Manfrotto 755XB Tripod

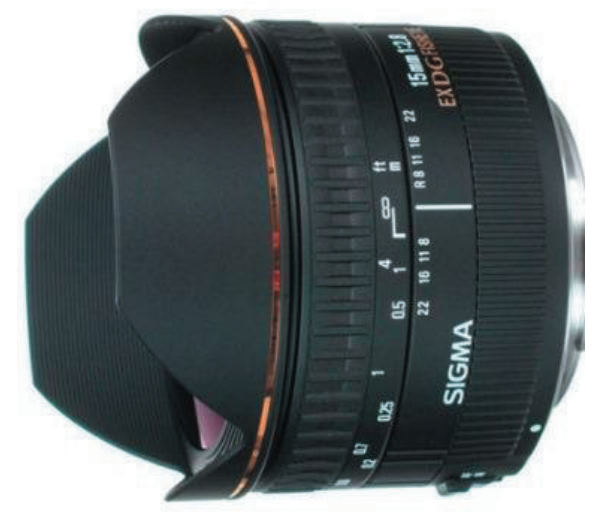

Fig. 2. Sigma 15mm EX DG Fisheye

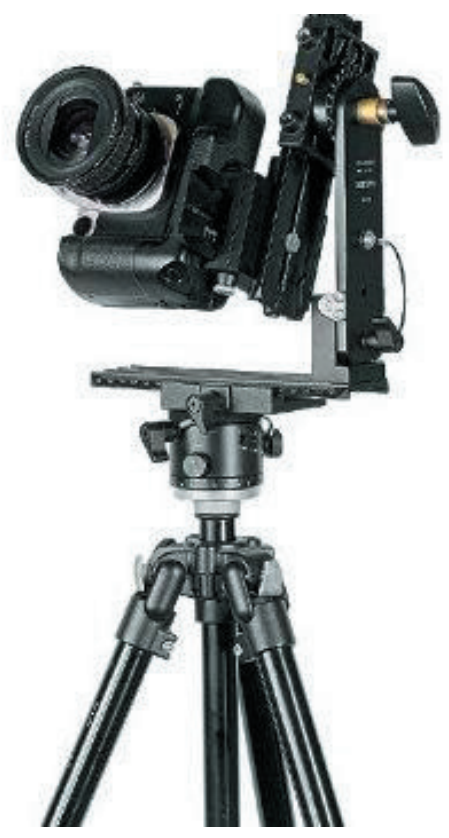

Fig. 4. Panoramic head of Manfrotto 303SPH

c) PTGui Pro v. 9.2.0. A convenient, functional program that provides the creation of cylindrical, flat and spherical, single-row and multi-row panoramas, based on any number of images.

\section{Discussion}

The main menu of Shushensky Bor information system is presented as a threedimensional map of the area with a view of the park's territory; contains sections focused on the user's demand, such as "Routes", "Explore the flora and fauna", "Explore the map". All the sections contain information corresponding to the names (Fig. 5). 


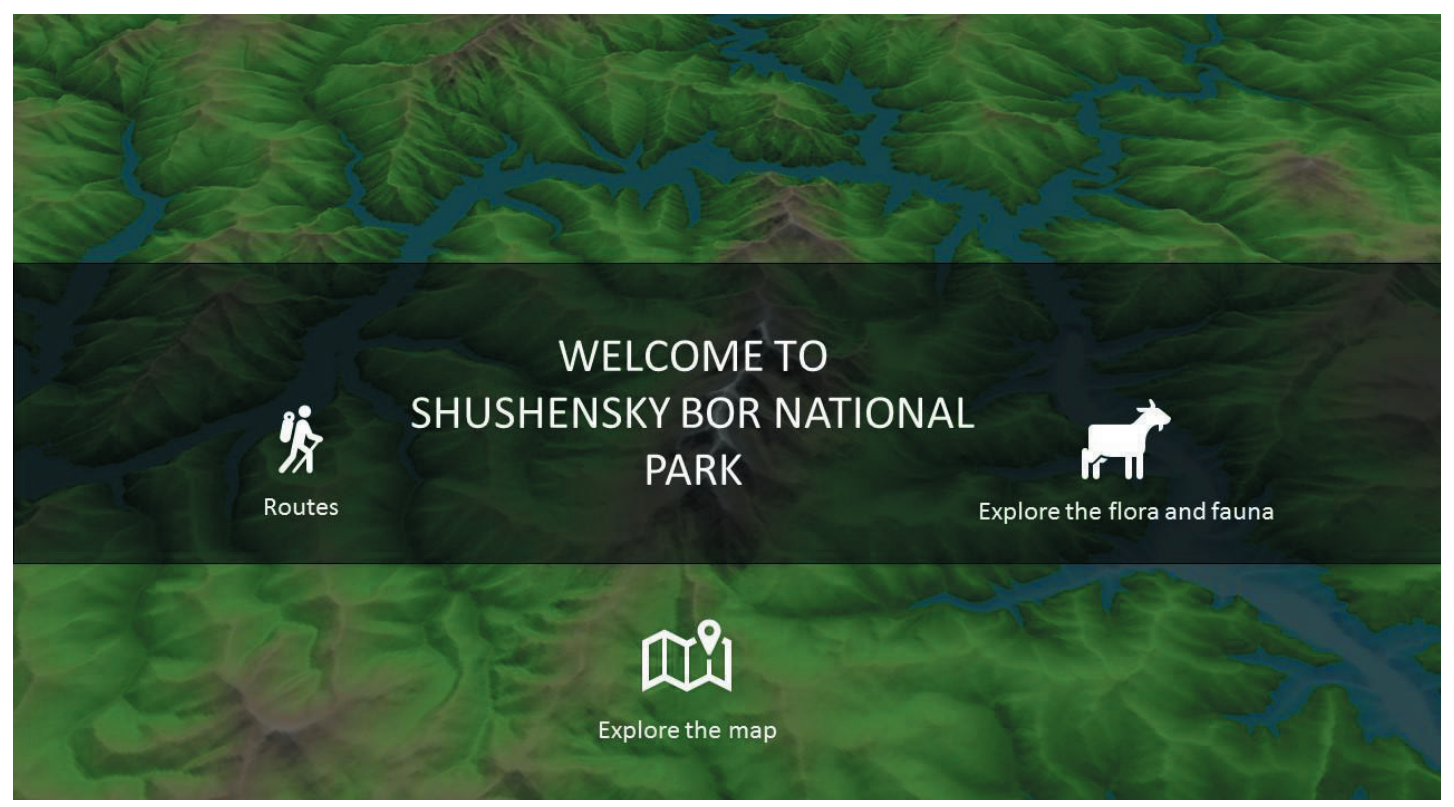

Fig. 5. Shushensky Bor IP home page

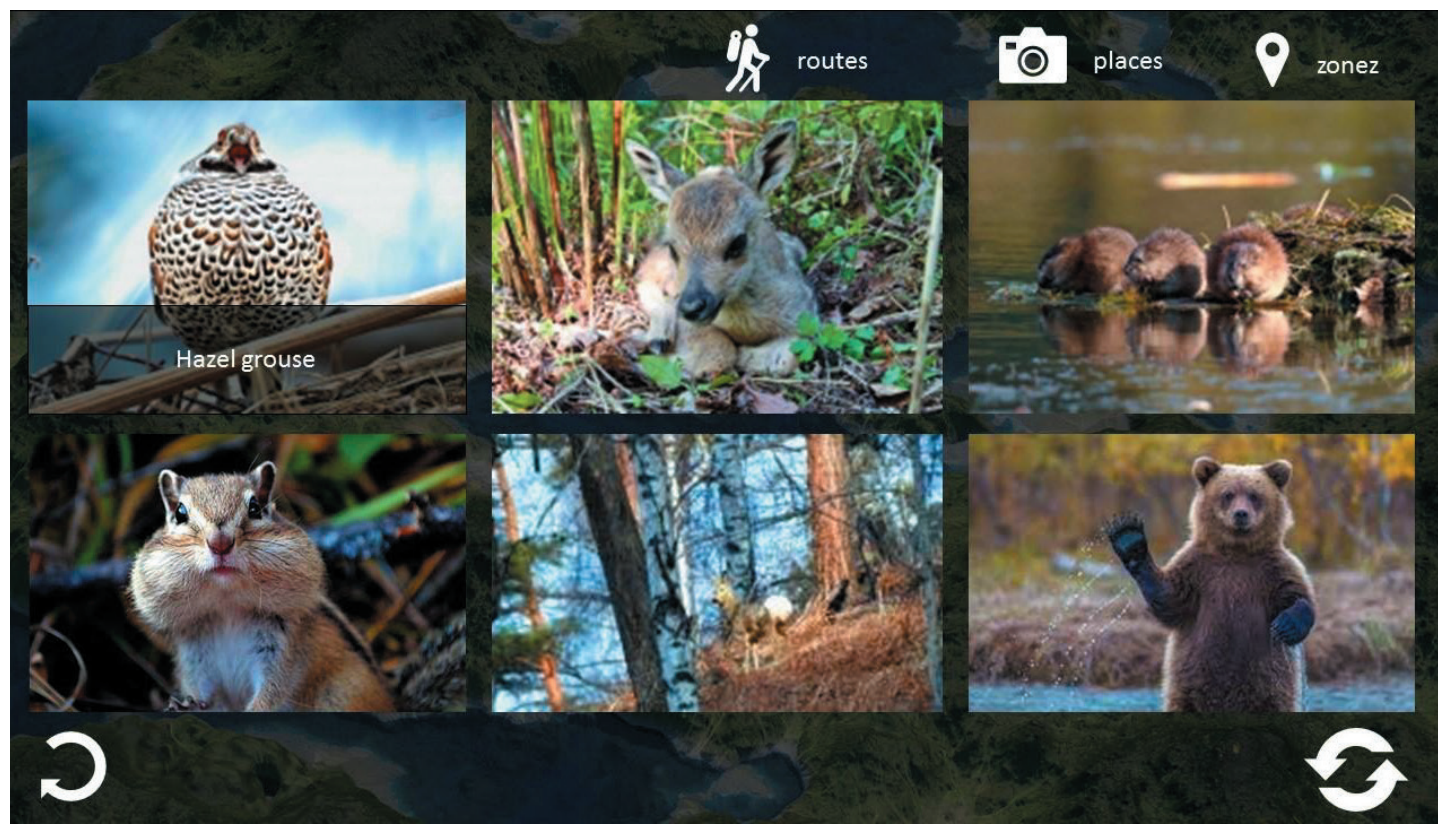

Fig. 6. Fauna section in Shushensky Bor IS

The created digital database directly on the information resource is presented in the Flora and Fauna and Zones sections, within which the user can obtain additional reference information about a specific object of the system (Fig. 6). 


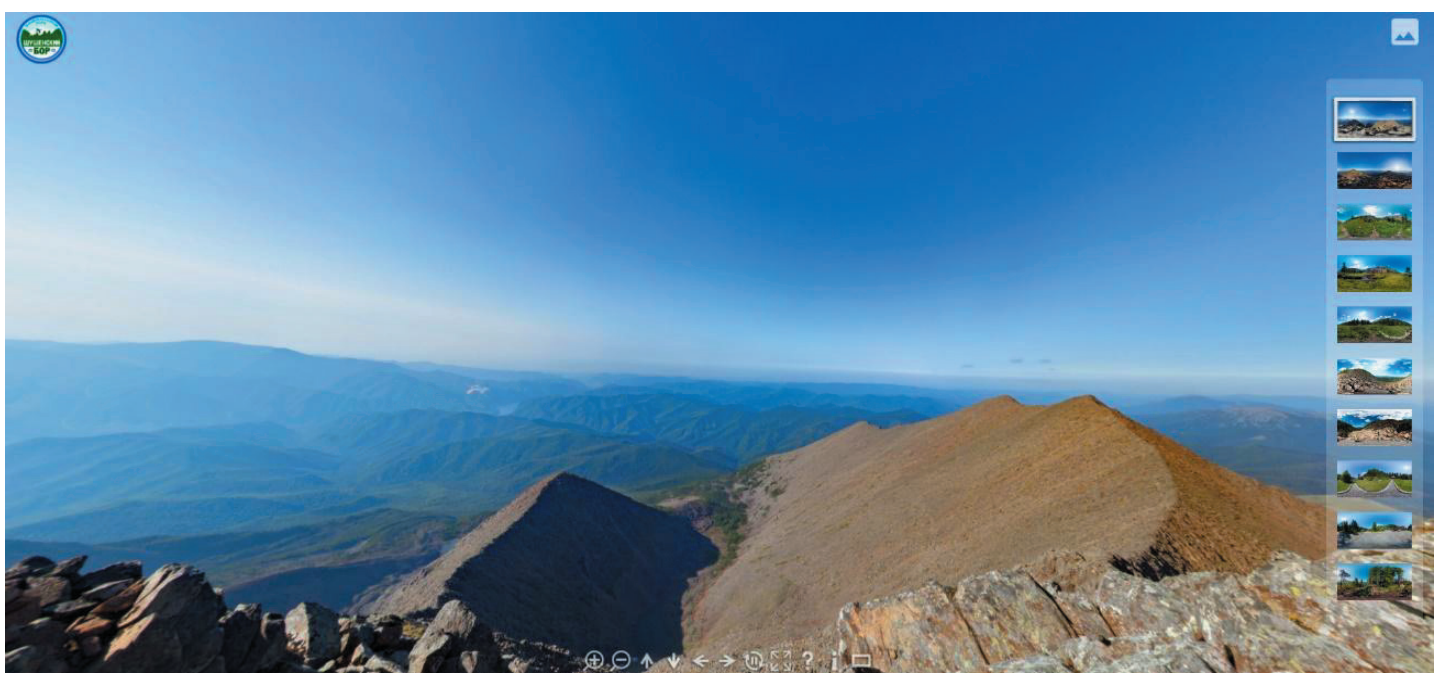

Fig. 7. Spherical panorama with a drop-down menu according to the panoramas'sketches in Shushensky Bor IS

The information system provides the ability to minimize the user interface for managing a three-dimensional map.

The virtual tour of Shushensky Bor national park is a separate web page, the transition to which is carried out from the corresponding section. The navigation panel consists of several buttons, namely navigation buttons, zoom buttons, a menu button with additional text information, and a tab with information about the project, as shown in Fig. 7.

Thus, the following materials were used in the work: texts on the national park on the basis of reports on the activities of Shushensky Bor National Park, photographs, panoramas of key locations obtained during field expeditions to the national park territory, infographics. The presented categories are contained in such sections as Tourist Routes, Explore the Map, Flora and Fauna, Places (panoramas), Zones (natural areas of the reserve).

\section{Conclusion / Results}

The result of the work was the information resource, which is an application software created with the use of the latest technologies (3D panoramas, WebGL, html 5), which combines an interactive map of the park, high-resolution quality digital images of the landscape and the flora of the park with the possibility of detailed elaboration, text descriptive data on the flora and fauna of the reserve. Thus, the information system combines a number of advanced IT solutions and technologies and provides all kinds of information needed to fully explore the natural territory. 
The sphere of use of this information product is culture, education, science. The information system can be applied in educational and scientific spheres, namely in nature protection activity, tourism, studying of geology and mineralogy, in scientific research and educational activity of cultural institutions. It allows the user to remotely get an idea of the diversity of the landscape and the wealth of archaeological and historical monuments of Shushensky Bor National Park.

It should be noted that the implementation of multifunctional, not only scientific and educational, but also cultural and leisure information systems can increase the attractiveness of the national park for tourists and researchers, attract young people who are confident in the digital ecosystem and have rich user experience.

\section{Acknowledgments}

We express our gratitude to the regional state autonomous institution "Krasnoyarsk Regional Fund for the Support of Scientific and Technical Activity" for financial support of the project.

We are grateful to Siberian Federal University for co-financing the project.

We are grateful to the administration of the Shushenskiy District of the Krasnoyarsk Territory for an expert evaluation of the results of the project.

\section{References}

Cipolla Ficarra,F.V., Nicol,E., Cipolla-Ficarra, M.(2011). Usability, communicability and cultural tourism in interactive systems: Trends, economic effects and social impact. In Lecture Notes in Computer Science (including subseries Lecture Notes in Artificial Intelligence and Lecture Notes in Bioinformatics). Vol. 6529 LNCS.

Hashim, K.H.B., Jusof, M.J.B. (2010). Spherical high dynamic range virtual reality for virtual tourism: Kellie's Castle, Malaysia. P. 297-300.

Jusof, M.J., Rahim, H.R.A. (2015). Revealing visual details via high dynamic range gigapixels spherical panorama photography: The Tempurung Cave natural heritage site. Institute of Electrical and Electronics Engineers Inc. P. 193-200.

Kucharska, M., Pochocka-Szwarc, K., Rychel, J., Krzywicki, T., Ber, A., Danel, W., Pielach, M. (2011). Geological-tourist maps of national parks in Poland. Mapy geologiczno-turystyczne parków narodowych. In Prz. Geol., 59 (4), 352-356.

Leonov, A. Serebrov, A., Anikushkin, M., Belosokhov, D., Bobkov, A., Eremchenko, E., Frolov, P., Kazanskiy, I., Klimenko, A., Klimenko, S., Leonova, V., Rashidov, A., Urazmetov, V., Aleynikov, A., Droznin, V., Dvigalo, V., Leonov, V., Samoylenko, 
S., Shpilenok, T. (2010). Virtual story in cyberspace: Valley of Geysers, Kamchatka: UNESCO natural heritage site in cyberworld. In 2010 International Conference on Cyberworlds. P. 247-253.

Leonov A., Aleynikov, A., Belosokhov, D., Bobkov, A., Eremchenko, E., Frolov, P., Klimenko, A. and Klimenko, S. (2011). 3D documentation of natural heritage for virtual environments and web - Case study: Valley of Geysers, Kamchatka. In IADIS International Conferences Computer Graphics, Visualization, Computer Vision and Image Processing 2011. P. 255-259.

Lukina, N.P. (2008). Information society: the state and prospects of sociophilosophical research, In Open interdisciplinary electronic journal "Humanitarian Informatics", 1. Available at: http://huminf.tsu.ru

O Strategii razvitiia informatsionnogo obshchestva $v$ Rossiiskoi Federatsii na 2017-2030 god [Decree of the President of the Russian Federation "On the Strategy for the Development of the Information Society in the Russian Federation for 2017-2030"] (2018). Available at: http://pravo.gov.ru/proxy/ ips $/$ ?docbody $=\&$ firstDoc=1\&lastDoc=1\&nd=102431687 (accessed 5 February 2018).

Remondino, F. (2011). Advanced 3D recording techniques for the digital documentation and conservation of heritage sites and objects. In University of Pennsylvania Press, 1 (2), 198-214.

Ryan, J.C. (2014). Natural heritage conservation and eco-digital poiesis: A Western Australian example. In Media International Australia, 153, 88-97.

Stepanitskii, V.B. (2002). Predlozheniia $k$ gosudarstvennoi strategii po razvitiiu sistemy gosudarstvennykh prirodnykh zapovednikov $i$ natsional'nykh parkov $v$ Rossiiskoi Federatsii na period do 2015 goda [Proposals to the state strategy for the development of the system of state nature reserves and national parks in the Russian Federation for the period up to 2015]. Moscow. Available at: https://wwf.ru/resources/ publications/booklets/predlozheniya-k-gosudarstvennoy-strategii-/

Talavera, A.S., Darias, A.J.R., Rodríguez, P.D. and Ávila, L.A. (2012). Facebook, heritage and tourism reorientation. The cases of Tenerife and Fuerteventura (Canary Isles, Spain). In Int. J. Web Based Communities, 8 (1).

The concept of the federal target program "Culture of Russia (2012-2018)" (2018). Available at: https://rg.ru/pril/65/68/74/209_ghu.doc (accessed 15 February 2018). 


\title{
Комплексная репрезентация природного наследия \\ на основе WebGL. Информационная система \\ «Шушенский бор»
}

\author{
Н.О. Пиков, М.Е. Романюк, \\ И.Н. Рудов, М.В. Румянцев \\ Сибирский федеральный университет \\ Россия 660041, Красноярск, Свободный, 79
}

\begin{abstract}
Рассмотрень проблемы и возможности сохранения и репрезентации объектов культурного и природного наследия в России с применением современных информационных технологий. Проведен анализ представленности особо охраняемых природных территорий в сети Интернет с точки зрения используемых технологий. Результат анализа показал, что в настоящее время способы представления национальных парков, заповедников, природных зон с туристическим потенциалом не соотносятся с потенциалом современных решений в области IT и обладают низкой степенью привлекательности для конечного потребителя.

Приведены примеры IT-решений, которые могут быть использованы для популяризаичи историко-культурного и природного наследия, но не применяются в данной области (такие как WebGL, 3D-панорамная фотосъемка, html 5, технологии трехмерного моделирования).
\end{abstract}

Изложена концепция комплексной информационной системы для репрезентации природного наследия на примере национального парка «Шушенский бор». Описаны этапы разработки системы и методология создания подобных информационных систем. Представлень скриншоты информационной системы «Шушенский бор», показана логика разделов и навигачии по системе. В заключительной части статьи описань характеристики программного обеспечения и оборудования, необходимого для получения качественного контента об объекте природного наследия и обеспечения функционирования комплексной системь его репрезентации.

Ключевые слова: трехмерная графика, 3D-моделирование, виртуальный тур, визуализачия, природное наследие, репрезентация природного наследия, национальный парк, заповедник, информационная система.

Исследование выполнено при поддержке краевого государственного автономного учреждения «Красноярский краевой фонд поддержки научной и научно-технической деятельности» в рамках реализации проекта: «Информационная система сохранения и репрезентации природного наследия (на примере охраняемой природной территории «Национальный парк «Шушенский бор»)».

Научная специальность: 05.13.01 - системный анализ, управление и обработка информации (по отраслям). 